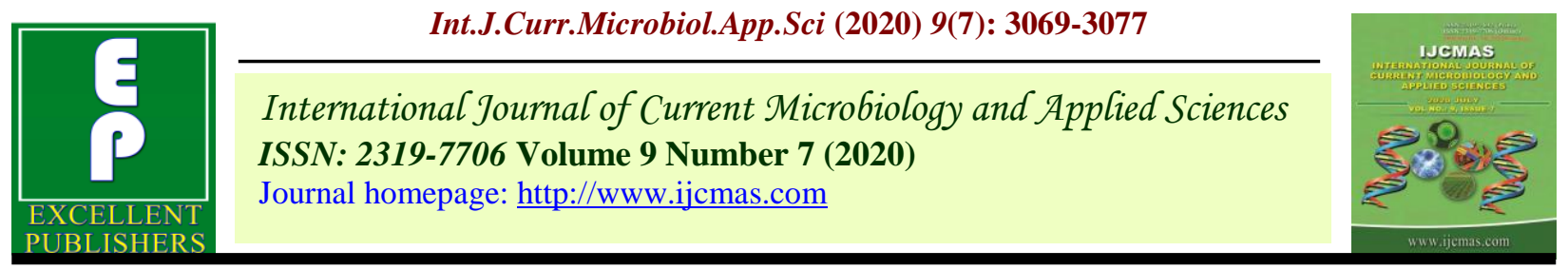

Original Research Article

https://doi.org/10.20546/ijcmas.2020.907.362

\title{
Direction of Trade and the Structural Stability of Indian Shrimp Exports: Markov Chain Analysis
}

\author{
K. J. V. K. Sirisha* and D. V. Subba Rao \\ Department of Agricultural Economics, ANGRAU, Lam, Guntur, A.P, India \\ *Corresponding author
}

\section{A B S T R A C T}

\begin{tabular}{|l|}
\hline Ke y w o r d s \\
$\begin{array}{l}\text { India, Markov } \\
\text { chain, Shrimp, } \\
\text { Trade direction. }\end{array}$ \\
\hline Article Info \\
$\begin{array}{l}\text { Accepted: } \\
\text { 22 June } 2020 \\
\text { Available Online: } \\
\text { 10 July } 2020\end{array}$ \\
\hline
\end{tabular}
In India shrimp is the one of the major item in seafood exports. It accounts for nearly $41 \%$ of total aqua exports. To study the direction of trade and the structural stability markov chain analysis was employed. The results showed that the growth performance was high for other pooled countries (OPC) i.e.16.6\% for quantity and $21 \%$ for value followed by South East Asia and $12.5 \%$ for quantity and $17 \%$ for value. Japan found to exhibit negative growth exports for shrimps. The results of direction of trade indicated that European Union and Other Pooled countries found to be highly loyal and stable markets for Indian frozen shrimps. However the ME and China found to be unstable importing countries for frozen shrimp exports from India.

\section{Introduction}

India's exports of marine products have their beginning as early as 1940s. During the year 1938-39 about 21,874 tonnes valued at 73.16 lakhs was exported. The exports are reached a level of 32,283 tonnes valued at 269 lakhs by 1945-46. Before 1960 the markets of Indian marine products were largely confined to neighboring countries like Sri Lanka, Myanmar, and Singapore etc. when our exports were dominated by dried items. (TNAU, 2015). The situation has changed with the development of technology and modernization dried products gave way to canned and frozen items. The frozen marine products exported include frozen shrimp, frozen fish, frozen cuttlefish, frozen squids and frozen lobsters etc. The shift in product also resulted the shift in market. The land mark in Indian seafood export was created when the first shipment of 13 tonnes frozen shrimp which valued Rs. 70,000 was sent to the United States in 1953 from Cochin (SEAI, 2017). More sophisticated and affluent markets viz. Japan, USA, Europe, South East Asian countries etc. became our important buyers. Several seafood processing units with modern machinery for freezing and production of value added products were set up at all important centers in the country for export processing. For a long time USA was the principal buyer for our frozen shrimp but after 1977, Japan emerged as the major buyer 
of the product followed by the European countries.

Exports of shrimp during 2017-18 was 5, 65,980 MT valued USD 4,848.19 million with USA continuing to be the largest market (2, 25,946MT) followed by SEA (1, 59,145 MT), EU $(78,426 \mathrm{MT})$, Japan $(33,828 \mathrm{MT})$, Middle East $(23,441 \mathrm{MT})$ and China (13, $107 \mathrm{MT})$. Frozen shrimp maintained its position as the key contributor to seafood export basket accounting for $41.10 \%$ in quantity and $68.46 \%$ of the total dollar earnings. (MPEDA, 2017). The objective of the present study is to examine the direction of the trade and structural stability of shrimp exports of shrimp exports using Markov chain analysis.

\section{Materials and Methods}

The data pertaining to shrimp exports of India during the period 1995- 96 through 20172018was obtained from the Marine Product Export Development Authority (MPEDA), Kochi.

\section{Markov chain analysis}

The changes in the exports of frozen shrimp to major importing countries were analyzed by employing a first order finite Markov chain model. It captures the net effect of changes in export of shrimps over a period of time. To study the structural change in frozen shrimp exports from India in terms of market retention and market switching was examined by using the Markov chain approach. The estimation of the transitional probability matrix $(\mathrm{P})$ was central to the analysis. The element $\mathrm{P}_{\mathrm{ij}}$ of the matrix indicates the probability that the exports would switch from the $\mathrm{i}^{\text {th }}$ country to $\mathrm{j}^{\text {th }}$ country over a period of time. The diagonal elements $P_{i j}$ indicates the probability that the export share of a country would be retained in the successive time periods which in other words, measures the loyalty of an importing country to a particular exporting country. In our study there are six major importing countries for Indian shrimp viz. Japan, USA, European Union, China, South East Asian countries, Middle East and all other countries grouped as others. The average exports to a particular country was considered to be a random variable which depends on its past exports and denoted algebraically in Eq. (1) as follows.

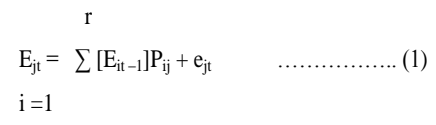

Where,

$E_{j t}=$ Exports from India to the $i^{\text {th }}$ country during the year $\mathrm{t}$

$\mathrm{E}_{\mathrm{it}-1}=$ Exports to the $\mathrm{i}^{\text {th }}$ country during the year $\mathrm{t}-1$

$P_{i j}=$ Probability that exports will shift from the $i^{\text {th }}$ country to $j^{\text {th }}$ country

$\mathrm{e}_{\mathrm{jt}}=$ Error-term which is statistically independent of $\mathrm{e}_{\mathrm{jt}-1}$ and

$r=$ Number of importing countries. $(r=7)$

The transitional probabilities $\mathrm{P}_{\mathrm{ij}}$, which can be arranged in a $(\mathrm{c} \times \mathrm{r})$ matrix, had the following properties:

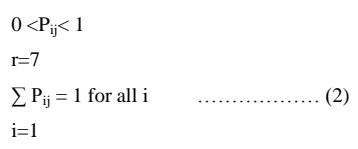

The expected export-share of India during a particular period $t$ was obtained by multiplying the quantity of exports to the selected countries (seven) during the previous period $(\mathrm{t}-1)$ with the estimated transition probability matrix (P).The transition probability matrix was estimated in the linear programming (LP) framework by a method referred to as minimization of Mean Absolute Deviation (MAD). The LP formulation on analysis was stated as per expression in equation 2 . 
Min $\mathrm{O} \mathrm{P}^{*}+\mathrm{Ie} \ldots \ldots . \quad \ldots$ (3)

Subject to

$\mathrm{XP}^{*}+\mathrm{V}=\mathrm{Y}$

$\mathrm{GP}^{*}=1$

$\mathrm{P}^{*} \geq \theta$

Where,

$\mathrm{P}^{*}$ is a vector of the probabilities $\mathrm{P}_{\mathrm{ij}}$

$\mathrm{O}$ is a null vector

I is an appropriately dimensional vector of areas

e is the vector of absolute errors $(|\mathrm{U}|)$

$\mathrm{Y}$ is the vector of exports to each country

$\mathrm{X}$ is a block diagonal matrix of lagged values of $\mathrm{Y}$

$\mathrm{V}$ is the vector of errors and

$\mathrm{G}$ is a grouping matrix to add the row elements of $\mathrm{P}$ arranged in $\mathrm{P} *$ to unity.

$\mathrm{P}^{*}$ vectors were arranged to obtain the transitional probability matrix which indicated the overall structure of the transitions that had taken place in the system. Essentially the transitional probability matrix captures the dynamics of the changes in shrimp exports from India. The individual probabilities $\mathrm{P}_{\mathrm{ij}}$ indicate the probability of the shift from the country $i$ to country $j$. Prediction of quantity of marine products exports were made by using the Transitional Probability Matrix.

$\mathrm{Bt}=\mathrm{B}_{0} * \mathrm{~T}$

$\mathrm{Bt}+\mathrm{i}=\mathrm{Bt}+\mathrm{i}-1 * \mathrm{~T}$

Where,

$\mathrm{B}_{0}=$ Quantity exported in Base year

$\mathrm{Bt}=$ Quantity exported in next year (prediction)

$\mathrm{T}=$ Transitional probability matrix

The values in the transition probability matrix will have different interpretations. The value of diagonal elements indicates the probability of retention of the previous year's share, while values in the columns reveal probability of gain by a particular country from other countries, values in rows reveal probability that a country might lose to other countries in respect of a specific commodity exports.

\section{Results and Discussion}

\section{Trade Directions to major importing markets: One step transitional probabilities}

The changing pattern of shrimp exports are estimated by the transitional probability matrices for the annual export data of shrimp for the period 20017-18presented in Table1. The six major importing countries of Indian shrimps are Japan, USA, EU, China, South East Asia and Middle East. Exports to remaining countries were pooled under the category of Other Pooled Countries (OPC). The retention coefficient along the diagonal probability matrix indicated the probability of retaining the current share of export for the forthcoming years.

From the figures in Table 1 that EU has been the most stable and loyal market for India as reflected by the higher probability of retention at 0.869 i.e., the retention of export share was around 86 per cent and gained the 59 per cent of export share from China. These results corroborated with the findings of Manjunath et al., 2017they found the direction of trade in marine products using Markov chain analysis and reported that European Union has been the stable importer i.e. the share of import by EU was 79 per cent followed by South East Asia 78 per cent. 
The Other Pooled Countries together have higher retention of export with share of 83 per cent and lost 16 per cent of shares to Middle East. USA has 78 per cent export retention and gained 58 per cent from Middle East, 23 per cent from South East Asian countries and 15 per cent from Japan. SEA has export retention of 76 per cent and had a probability of 23 per cent of share to USA.

The Japan has 72 per cent export retention and lost to 15 per cent shares to USA. It gained from the share of China to an extent of 24 per cent as well 14 per cent from Middle East.

The ME countries and China are found to be the most unstable importing countries with 26 per cent and 15 per cent retention shares respectively. China has lost 58 per cent of export share to EU and 24 per cent of export share to Japan.

The Middle East countries have also lost 58 per cent of shares to USA and 14 per cent of shares to Japan. This attributed to China and Middle East countries to become peting in shrimp exports.

They have huge aqua production base as well as more domestic consumption thus tacking a share of Indian shrimp exports resulting in high instability in trading.

\section{Estimation of Indian frozen shrimp exports to major importing countries}

Using the one- step transition probability the estimated shares frozen shrimp were compared with actual export shares. In Table 2 the actual and estimated shares in all the countries are revealed and the differences were by and large small. The calculated chi square value was less than table value at $96 \mathrm{df}$ indicating that the observed and the predicted proportions of exports of frozen shrimp are identically distributed. The estimated shares of shrimp were derived from the Markov process by validating the Markov chain model.

Japan, EU and USA are found to be major importers of Indian frozen shrimp accounting for about $61 \%$ of export share. Japan is the major importer in 2001-02 with about 25\% share, remained the major importer up to 2003-04 after which its share decreased due to continuous depreciation in Japanese Yen and antibiotic issues. Japan food safety commission announced in September 2012 regulations imposing compulsory testing for Ethoxyquin in shrimp consignment i.e. Ethoxyquin levels upto $0.01 \mathrm{ppm}$ only were acceptable unlike the previous 1ppm.Ethoxyquin is a quinolone based antioxidant used as a food preservative and pesticide.

Table.1 Transitional probability matrix of frozen shrimp exports from India

\begin{tabular}{|c|c|c|c|c|c|c|c|}
\hline COUNTRY & JAPAN & USA & $\mathbf{E U}$ & CHINA & $\begin{array}{l}\text { SOUTH } \\
\text { ASIA }\end{array}$ & $\begin{array}{l}\text { MIDDLE } \\
\text { EAST }\end{array}$ & OPC \\
\hline JAPAN & 0.726 & 0.153 & 0.058 & 0.047 & 0 & 0.014 & 0 \\
\hline USA & 0 & 0.784 & 0.019 & 0.035 & 0.086 & 0.038 & 0.036 \\
\hline $\mathbf{E U}$ & 0.074 & 0 & 0.869 & 0 & 0 & 0.031 & 0.025 \\
\hline CHINA & 0.249 & 0 & 0.589 & 0.156 & 0 & 0 & 0.005 \\
\hline SOUTH EAST ASIA & 0 & 0.238 & 0 & 0 & 0.762 & 0 & 0 \\
\hline MIDDLE EAST & 0.14 & 0.5815 & 0 & 0 & 0 & 0.269 & 0 \\
\hline OPC & 0 & 0 & 0 & 0 & 0 & 0.169 & 0.830 \\
\hline
\end{tabular}


Table.2 Actual and Estimated shares (\%) of shrimp exports from India

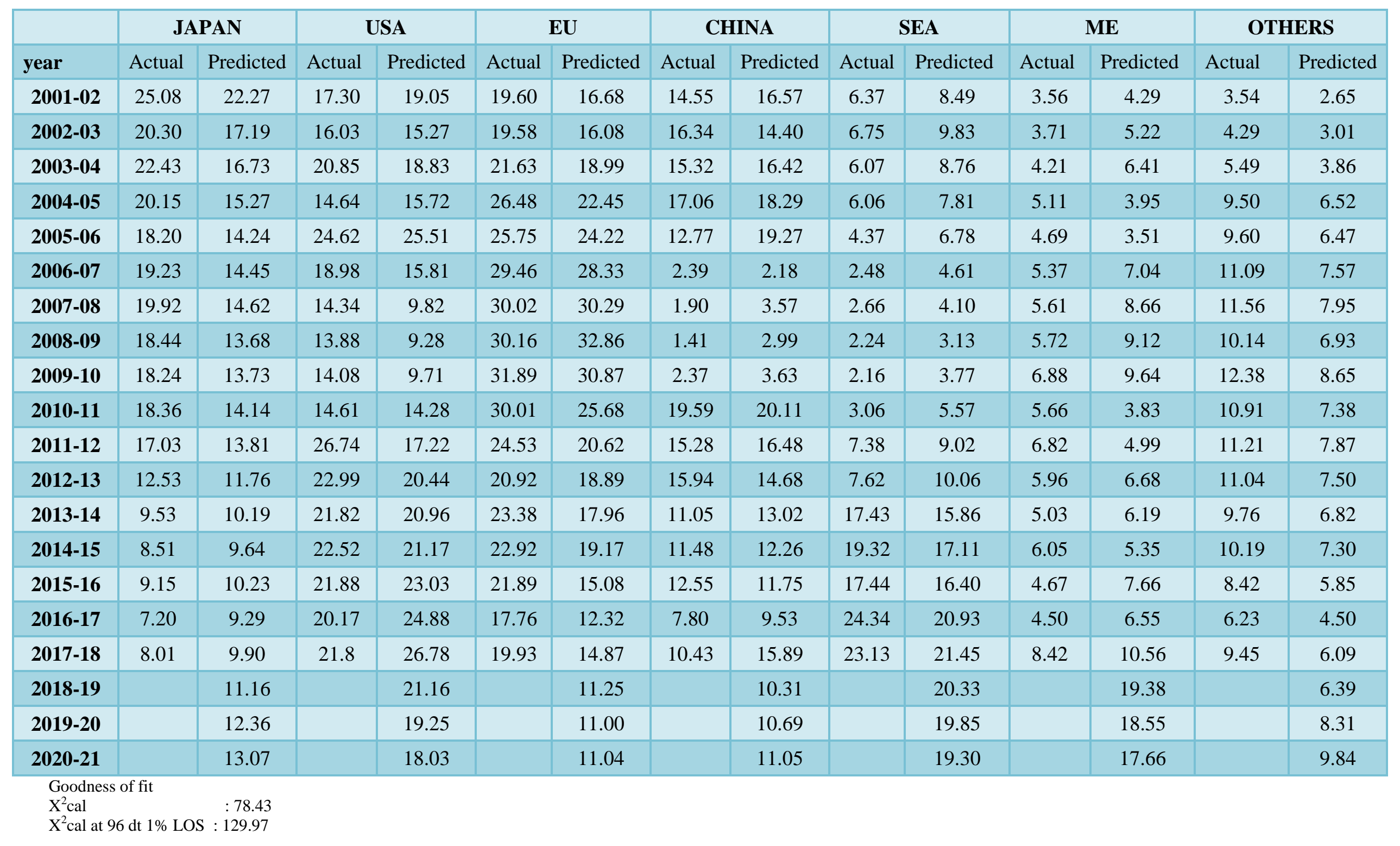


Fig.4.27 Actual and predicted trends of shrimp export to major markets from India
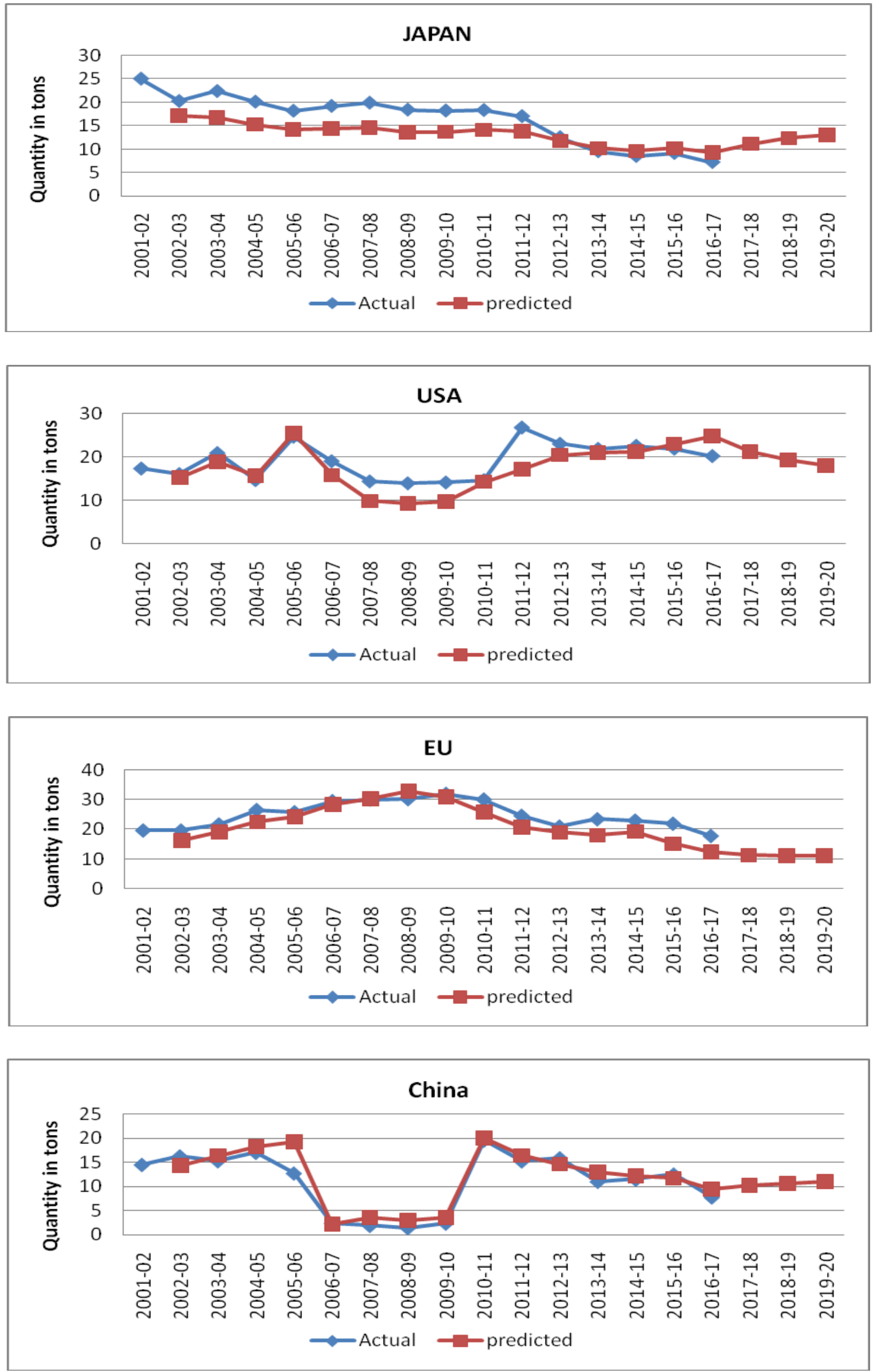

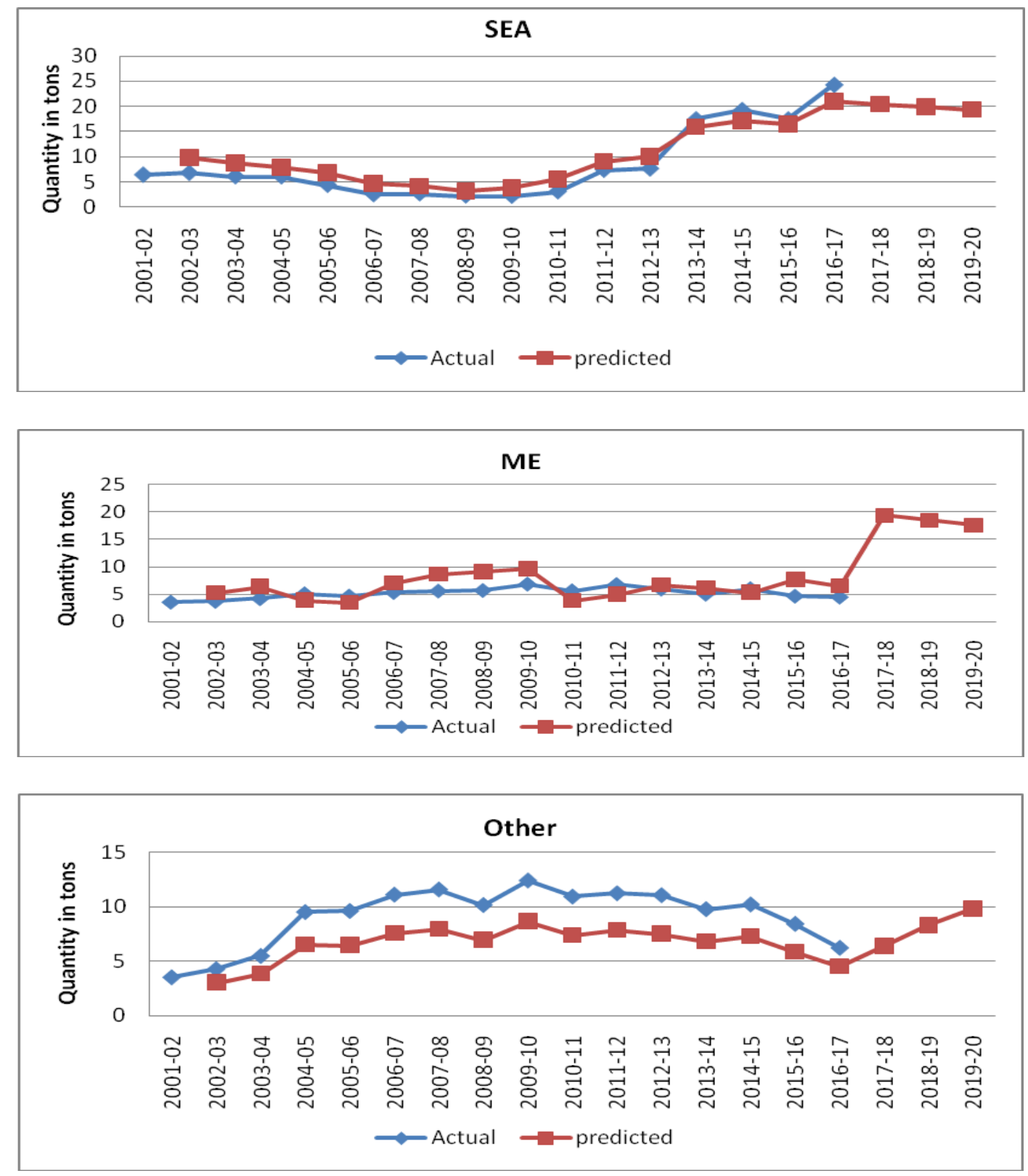

Antibiotic issues with frozen shrimp are responsible for the decline in exports. In the year 2012-13 exports of frozen shrimp decreased by $11.07 \%$ in quantity and $21.92 \%$ in terms of dollars mainly due to ethoxyquin issue with shrimp exports from India (MPEDA, 2013).The expected shares as estimated based on Markov model over the years is more or less near to the observed values indicating the validity of the fitted model. The share of shrimp which commanded higher price in an export basket to USA has recorded increase in shares up to 2005 and then shares decreased up to certain extent from year 2005-06 onwards due to the US antidumping duty on frozen shrimp (10\% value of exports) it can hold up to 3 years (Raghuram and Asopa, 2008, Sathiadhas et al., 2012). Consequently the export shares shifted to EU from USA. EU was the major market. i.e., shares have increased from $19.6 \%$ to $31.89 \%$ up to $2009-10$ and then decreases to $17.76 \%$. Indian seafood exporters were banned to European countries mainly 
due to the detection of antibiotics residues. European countries have zero tolerance limits for antibiotics in contrast to some other countries. The sampling scale of European countries has increased due to these quality issues from 10 percent to 50 percent and could eventually be increased to 100 percent. The observed and expected shares of Indian shrimp over the years has not shown much variation.

The actual shares of China in shrimp exports show fluctuation during the study period. Overall it is decreased from $14.55 \%$ to $7.8 \%$ between 2001-02 to 2017-18. Similar trend was observed in estimated share of exports which decrease from $16.57 \%$ to $9.53 \%$. In case of SEA there is significant increase in export shares from $6.3 \%$ to $24.34 \%$. The estimated values here similar trend with observed values. Malaysia and Thailand are important markets for raw materials where imported shrimp are mostly being reprocessed into value-added products and reexported to other developed markets. Imports of fresh/frozen shrimp into Thailand have been growing steadily from only 1,088 MT in 1990 to 14,492 MT in 1998. Current imports of shrimp into Malaysia are around 20,000 MT. Indonesia and Vietnam also import shrimp as raw materials to feed their processing industries. In 1997 Indonesia imported 1,453 MT of frozen shrimp. Middle East countries export share was more or less same during the overall period which is $3.56 \%$ in 2001-02 to $4.5 \%$ in 2016-17. Estimated values following the similar trend like observed values. The major factor determining the diversion of exports towards South East Asia and the Middle East was the less strict quality standards in these countries compared to USA and EU. (Sathiadhas et al., 2012.) The actual export shares of other countries (i.e. Russia, Republic of Korea, Australia, Egypt etc.,) show increasing trend up to $12.38 \%$ for the year $2009-10$ and then decreases. But overall period it is in increasing from $3.59 \%$ to $6.23 \%$. In case of estimated values it is significantly increasing from $2.65 \%$ to $9.84 \%$. If there are some instances of differences in few years these are mainly due to limitations of the model that the present estimates depend only on the previous year's observations.

In conclusion the changing pattern of shrimp exports exhibits the $\mathrm{EU}$ has been the most stable market as reflected by the higher probability of retention at $86 \%$ followed by other countries with share of $83 \%$. The USA and Japan have $78 \%$ and $72 \%$ export retention respectively. The ME and China are found to be unstable importing countries with $26 \%$ and $15 \%$ retention shares respectively. The direction of trade indicates that the European Union and other polled countries were found to be highly loyal markets for Indian shrimp.

By looking to the estimated growth rates of frozen shrimp exports from India to other pooled countries in quantity terms was found to be $16.6 \%$ and $21 \%$ with value followed by SEA countries with growth rate of $12.5 \%$ for quantity and $17 \%$ for value. Japan was found to be negative growth rate due to depreciation in Japan Yen and Ethoxyquin issues. The estimated growth rates for USA and EU was slightly decreases due to tariff and SPS agreements.

\section{References}

Esawarprasad, Y., Lalithachoth and Radha, Y. 1997. Farm technology in relation to changing structure of land holdings. Agricultural economics research review.10(2): 78-87.

Majunath N., Lokesha H. and Deshmanya B. J. 2017. Direction of trade and changing pattern of Indian marine products exports. Indian journal of Agricultural research. 51(5): 463-467. 
MPEDA. 2013. Annual report-2012-13. Ministry of Commerce and Industry, Government of India. MPEDA. 2017. Annual report-2016-17. Ministry of Commerce and Industry, Government of India.

Raghuram, G and Asopa, V. N. 2008. Issue in infrastructure for Export of marine products from India. Central marine fisheries research institution. Kochi.
Sathiadhas, R. Narayanakumar, R and Aswathy, N. 2012. Marine Fish Marketing in India. Central Marine Fisheries Research institution, Kochi. SEAI .2017 http://seai.in/history (Accessed on $21 / 08 / 2018$ )

TNAU. 2017

http://agritech.tnau.ac.in/fishery/fish_ex port.html (Accessed on 21/08/2018)

\section{How to cite this article:}

Sirisha, K. J. V. K. and Subba Rao, D. V. 2020. Direction of Trade and the Structural Stability of Indian Shrimp Exports: Markov Chain Analysis Int.J.Curr.Microbiol.App.Sci. 9(07): 30693077. doi: https://doi.org/10.20546/ijcmas.2020.907.362 